\title{
A Case of Aggressive Floor of the Mouth Cancer During Pregnancy
}

\section{Gebelikte Hızlı Seyir Gösteren Ağız Tabanı Kanseri Olgusu}

Osman Fatih Boztepe ${ }^{1}$,

Taylan Gun²,

Harun Dogru ${ }^{1}$,

Koray Coskunfirat ${ }^{1}$,

Yildiz Keles ${ }^{1}$

${ }^{1}$ Medical Park Antalya Hospital, Antalya

${ }^{2}$ Bahcesehir University Faculty of Medicine,

Ankara Medical Park Hospital, Ankara.

Gelis Tarihi/Received: 18 January 2016 Kabul Tarihi/Accepted: 31 May 2017

\begin{abstract}
Öz
Oral skuamoz hücreli karsinoma, oral kavitenin en sık görülen tümörüdür. Gebelik sırasında, ağız tabanı karsinomu ise literatürde henüz bildirilmemiştir. 26 yaşında, 34 haftalık gebe hasta kliniğimize ağızda kitle şikayeti ile başvurdu. Yapılan KBB muayenesinde, sol ağız tabanında, ülsere, frajil, $2 \times 1 \mathrm{~cm}$ genişliğinde ve 6-7 mm derinliğinde kitle izlendi. 8 günde, tümör iki katına çıktı. Median mandibulutomi yapılarak tümöre transmandibuler yolla ulaşıldı ve en blok olarak boyun disseksiyonu materyali ile çıkarıldı. Gebelik sırasında tespit edilen oral skuamoz hücreli karsinomalar hızlı bir şekilde tedavi edilmeli. Hasta ve yakınları, bekleme durumunda, hastalığın progresyonu konusunda uyarılmalıdır.
\end{abstract}

Anahtar Kelimeler: Gebelik-ağız tabanı-skuamoz hücreli karsinoma

\section{Abstract}

Oral squamous cell carcinoma (OSCC) is the most frequent malignancy of the oral cavity. Squamous cell carcinoma of floor of the mouth during pregnancy is not reported in the literature. 26-year-old female patient admitted to our clinic with a lesion in the mouth for 2 weeks. The patient was 34 weeks pregnant and non-smoker. ENT examination revealed that the fragile, ulcerated, $2 \times 1 \mathrm{~cm}$ width and 6-7 $\mathrm{mm}$ depth lesion was on the left side of the floor of mouth. In eight days, the tumour was almost double in size. Median mandibulotomy was applied to facilitate the resection of the tumor via transmandibular way and the tumour was removed en bloc together with the neck dissection specimen. The patients with oral squamous carcinomas during pregnancy should be treated more quickly, patients and families should be informed about the tumor progression.

Keywords: Pregnancy, Floor of the mouth, Squamous cell carcinoma

\section{INTRODUCTION}

Oral cancers account for approximately 10\% to $14 \%$ of head and neck malignancies (1). Oral squamous cell carcinoma (OSCC) is the most frequent malignancy of the oral cavity (2).

Head and neck squamous cell carcinoma (HNSCC) is typically considered to be a disease that predominantly affects older men, with a male:female ratio of approximately $4: 1$ and one in 118 women diagnosed with cancer is pregnant at the time of diagnosis $(3,4)$. However, for a surgeon seeing a case of oral carcinoma in pregnancy is extremely rare 5 . Oral cancer accounts for less then $2 \%$ of all cancers during pregnancy (5).

Squamous cell carcinoma of floor of the mouth is not reported in the literature before but the tongue carcinoma is the most common oral cancer reported during pregnancy (5-7).

\section{CASE}

26-year-old female patient admitted to our clinic with a lesion in the mouth for 2 weeks. The patient was 34 weeks pregnant and non-smoker. ENT examination revealed that the fragile, ulcerated, $2 \times 1 \mathrm{~cm}$ width and $6-7 \mathrm{~mm}$ depth lesion was on the left side of the floor of mouth. No palpable lymphadenopathies in the neck were detected. Incisional biopsy under local anesthesia was performed and the result was reported as well differentiated squamous cell carcinoma. Because of the pregnancy, only MRI and US imaging studies could be performed and the results showed that the lesion was not delineated from the adjacent tissues due to the regional edema and inflammation, however, the mass was reaching to the mandibula periostium but was not invading the tongue muscles. TNM staging was T2 NO MO - stage 2. Same day c-section and pull-through resection with ipsilateral 


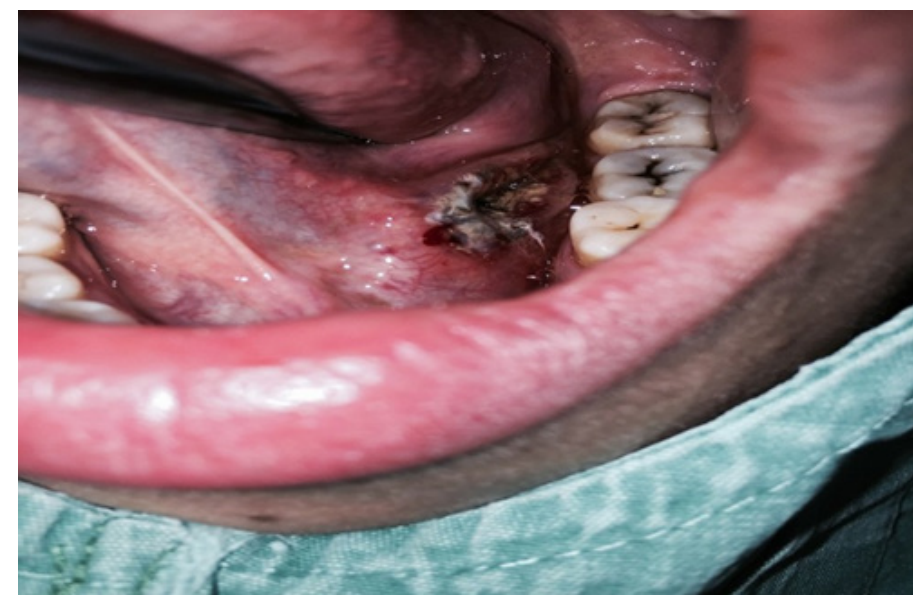

Figure 1. Preoperative appearance of the tumour

neck dissection was planned but the patient did not accept the operation. After eight days, the patient was admitted to our clinic again. Tumor size was seen to have reached to $5.5 \times 3 \mathrm{~cm}$ from the first day to 22nd day when the operation was performed. The perioperative depth was measured approximately 1.5 $\mathrm{cm}$. Median mandibulotomy was applied to facilitate the resection of the tumor via transmandibular way and the tumour was removed en bloc with the neck dissection specimen. Perioperative frozen studies were reported as negative surgical margins. Large defect in the floor of the mouth was reconstructed with pectoralis major musculocutaneous flap. 1 positive lymph node metastasis was detected in the ipsilateral middle cervical region after the pathological examination. Thereupon, after the detection of lymph

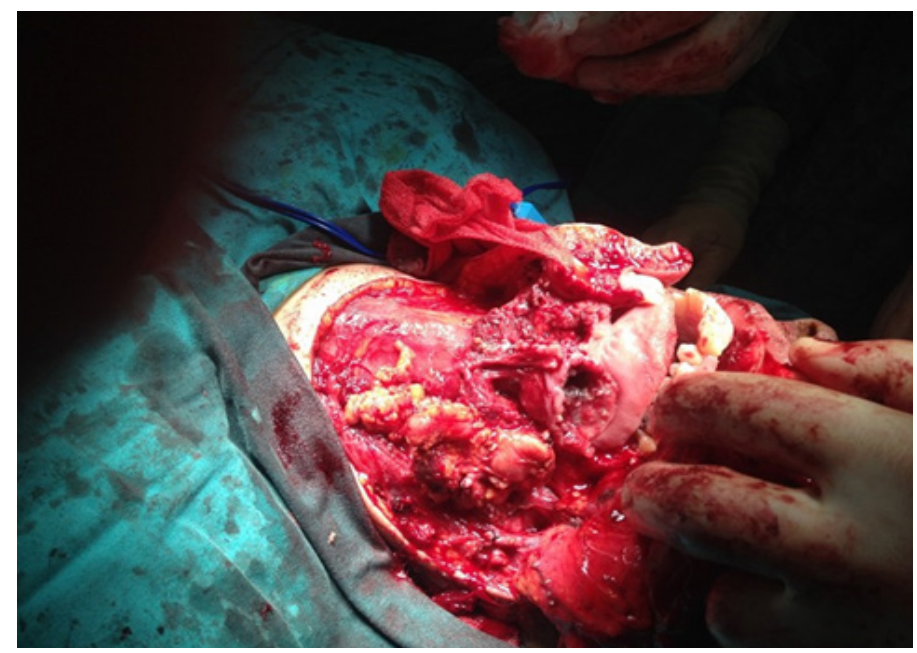

Figure 2. Intraoperative appearance of the tumour node metastasis, contralateral neck dissection was performed after 4 weeks. There was no evidence of distant metastases in the patient's assesment by PET. In light of these findings, according to the TNM classification, it was staged as - Stage 4a. Concomitant chemotherapy and radiotherapy was planned at postoperative 1 th month. The patient had received cycles of cisplatin and 50Gy boost bilateral neck radiotherapy with 66 Gy IMRT technique. The patient is in the remission period now.

\section{DISCUSSION}

Cancer of floor of mouth is a very rare condition during pregnancy and never reported in the literature before. However, the rarity of the condition means it is impossible to acquire any experience and equally difficult to accumulate any collective data from different centers.

Long-term alcohol and tobacco use have been identified as the traditional risk factors for oral cavity SCC (6). Interestingly, recent trends have shown an increase in the incidence of HNSCC in younger patients without these risk factors, and there is controversy over whether these represent a more aggressive form of cancer (7).

HPV-positive oropharyngeal cancers are also associated with younger age at diagnosis and may arise in people without a history of tobacco use (8). Pregnancy may induce physiologic changes that can promote neoplastic growth, such as a high metabolic state, increased circulating growth factors, and amplified hormonal responses mediated through the estrogen and progesterone receptors (5,7-9).

Cheng et al. (10) studied on placenta growth factor's effect about progression and prognoses of oral cancer and the found that the PIGF labeling index in OSCC samples was significantly correlated with $\mathrm{N}$ classification and clinical staging of OSCCs. Moreover, patients with OSCC with higher PIGF labeling indices had a poorer cumulative survival than patients with lower PIGF labeling indices (11).

When HNSCC is diagnosed in a pregnant patient, clinicians and patients are faced with the challenge of balancing maternal and fetal health. Although early detection and intervention are key, it is also important to weigh the risks of diagnostic and treatment modalities to the fetus. The patient is faced with difficult ethical decisions, and the clinician is often tasked with providing both optimal treatment for the cancer and protection of the fetus 8 .

Treatment of an oral cancer occurring during 
pregnancy depends on the prognosis of the specific malignancy (type, site, and stage of tumor), the course of the pregnancy, and the wishes of the patient and her spouse 7.

In our case, the delay of the surgery caused an aggressive increase of the tumor size and tumor progression in patient with Stage 4 to Stage 2 after the diagnosis of squamous cell carcinoma of floor of the mouth in pregnancy, the patient should be treated more quickly, patients and families should be informed about the tumor progression. The link between oral cancers and pregnancy has yet to be firmly established, and more etiological studies are urgently required to better understand and manage this condition.

\section{Acknowledgements}

The authors received no grants or other scientific support related to the preparation of this manuscript.

Conflict of interest: Authors declare that there is no conflict of interest between the authors of the article.

Financial conflict of interest: Authors declare that they did not receive any financial support in this study.

Address correspondence to: Taylan Gün, Bahcesehir University Faculty of Medicine, Ankara Medical Park Hospital, Ankara, Turkey Ankara, Turkey

E-mail: taylangun@gmail.com

Phone: +90 5323435019 Fax: +90 2122273477

\section{REFERENCES}

1. Davies L, Welch HG. Epidemiology of head and neck cancer in the United States. Otolaryngol Head Neck Surg 2006;135(3):451-7.

2. Massano J, Regateiro FS, Januario G, et al. Oral squamous cell carcinoma: Review of prognostic and predictive factors. Oral Surg Oral Med Oral Pathol Oral Radiol Endod. 2006;102(1):67-76.

3. Jemal A, Siegel R, Ward E, et al. Cancer statistics, 2009. CA Cancer J Clin 2009;59(4):225-49.

4. Donegan WL. Cancer and Pregnancy. CA Cancer J Clin 1983;33(4):194-214.

5. Layton SA, Rintoul M, Avery BS. Oral carcinoma in pregnancy. Br J Oral maxillofac surg1992;30(3):161-4.

6. Shiboski $\mathrm{CH}$, Schmidt $\mathrm{BL}$, Jordan $\mathrm{RC}$. Tongue and tonsil carcinoma: Increasing trends in the US population ages 2044 years. Cancer 2005;103:1843-9.

7. Lasaridis N, Tilaveridis I, Karakasis D. Management of a carcinoma of the tongue during pregnancy: Report of case. J Oral Maxillofac Surg 1996;54(2):221-4.

8. Shibuya H, Saiot M, Horiuchi JI, et al. Treatment of malignant head and neck tumors during pregnancy-a report of 3 cases. Acta Oncol 1987;26(3):237-8.

9. Eliassen AM, Hauff SJ, Tang AL, et al. Head and neck squamous cell carcinoma in pregnant women. Head Neck. 2013;35(3):335-42.

10. Cheng SJ, Lee JJ, Kok SH, et al. Expression of placenta growth factor: An independent factor for prediction of progression and prognosis of oral cancer. Head Neck. 2010;32(10):1363-9. 